\title{
Effect of Organic and Inorganic Fertilization on Yield and Quality Traits of Tritordeum, 'Bulel’ Variety under Dry Conditions in Greece
}

\author{
Antigolena FOLINA ${ }^{1}$, Ioanna KAKABOUKI ${ }^{1}$, Efpraxia KONTONASAKI ${ }^{1}$, Stella KARYDOGIANNI ${ }^{1}$, Dimitrios \\ VOSKOPOULOS $^{1}$, Dimitrios F. BESLEMES ${ }^{2}$, Dimitrios BILALIS ${ }^{*}$ \\ ${ }^{1}$ Lab of Agronomy, Agricultural University of Athens, School of Plant Sciences, Department of Crop \\ Science, Laboratory of Agronomy, 75 Iera Odos St, 11855, Athens Greece. \\ ${ }^{2}$ Research \& Development manager, Alfa seeds ICSA/Seed production and commerce/10th km \\ Mesorachis-Ag. Georgiou, Larisa, 41500, Greece \\ *corresponding author: bilalisdimitrios@gmail.com
}

BulletinUASVM Horticulture 77(2) / 2020

Print ISSN 1843-5254, Electronic ISSN 1843-5394

DOI:10.15835/buasvmcn-hort: 2020.0056

\begin{abstract}
Response of tritordeum, 'Bulel' variety, on organic and inorganic fertilization was observed through a field experiment in Greece. So as to evaluate, a field experiment was set up in Randomized Complete Block Design (RCBD) where blocks were four fertilizations (control, inorganic, manure, compost). Plant height was affected by fertilization. Thus height was ranged from $65 \mathrm{~cm}$ (control) to $71.75 \mathrm{~cm}$ (NPK). Concerning, kernel weight, control and the two organic fertilized did not differ. Both protein and gluten has a positive response to inorganic fertilization, values were $16.27 \%$ and $33.45 \%$ respectively. The increase in gluten is not a desirable trait as tritordeum is cultivated for lower gluten levels than wheat. Yield rised with fertilizers with the highest value of $4753.5 \mathrm{~kg} \mathrm{ha}^{-1}$. In brief, as first results, there was a positive response of tritordeum to fertilization in the dry conditions of Greece. As far as 'Bulel' variety recently became commercial, consequently a few years to further investigate are needed.
\end{abstract}

Keywords: tritordeum, Bulel variety, fertilization, protein content, gluten content

\section{Introduction}

Cereals are at the base of the food pyramid and are the center of a balanced diet. A new species is the tritordeum (xTritordeum martinii A. Pujadas, nothosp. nov.). The breeders of this new type of grain tried to maintain the properties of wild relatives of Hordeum vulgare (Hordeum chilense Roem. Et Schultz.) and cultivated durum wheat (Triticum turgidum ssp. Durum Desf). Feuillet et al., in 2008 report that tritordeum failed to gain commercial acceptance. But three years later, the recording of the first commercial variety, 'Aucan' is done (2011) and five years after (2013) is released the second commercial cultivar, 'Bulel'. The newly- created cereal is proper for human consumption and suitable for a wide range of cereal-based products in bakery and confectionery industry.

Tritordeum gained space due to improved quality and wheat bread characteristics. Vaquero et al. (2017), comparing the response of some volunteers to wheat bread and tritordeum bread, showed that tritordeum can restore wheat bread due to lower gluten levels.

The quality of cereals, except for genetic characteristics, are significantly influenced by cultivation techniques. Fertilization is one of these practices. De Santis et al. (2020) report that nitrate fertilization affects the quality of wheat 
flour. Besides, Blandino et al. (2020) mention that late application of $\mathrm{N}$ fertilizer influenced gluten composition and increased protein content.

The purpose of this study was to create knowledge about the cultural care in tritordeum cultivation. Tritordeum is considered as a novel crop through Europe and Greece. Most researches on this new cereal concern breeding and the quality characteristics of seeds. Like all crops it is directly related to cultivation practices and climatic conditions. As a result, a knowledge gap was created and our study was set up. The effect of inorganic and organic fertilization was studied in non-irrigated tritordeum cultivation in Greece. The agronomic traits and yield of the amphiploid Hordeum chilense $\times$ Triticum turgidum conv. durum were observed under dry field conditions. Additionally, some quality characteristics, such as grain protein content, gluten, seed moisture capacity and seed fiber, have been studied in inorganic and organic fertilization.

\section{Material and methods} Experimental design

A field experiment was set up in experimental field of Laboratory of Agronomy, in Agricultural University of Athens laboratory of Agronomy (37 $59^{\prime} 01.83^{\prime \prime} \mathrm{N}, 23^{\circ} 42^{\prime} 07.37^{\prime \prime} \mathrm{E}$ and altitude $30 \mathrm{~m}$ ). The soil is classified as a Clay Loam (35.9\% sand, $29.8 \%$ clay and $34.3 \%$ silt), with pH 7.29 (1:1 water
$\mathrm{H}_{2} \mathrm{O}$ ) and $2.37 \%$ organic matter content (Wakley and Black, 1934). For chemical characterization of soil for control treatment, Polsen $=25 \mathrm{ppm}, \mathrm{N}-\mathrm{NH} 4^{+}$ $=15 \mathrm{ppm}, \mathrm{N}-\mathrm{NO}_{3}^{-}=11 \mathrm{ppm}$ and $\mathrm{K}=230 \mathrm{ppm}$. Weather data (rainfall and average temperature) of the experimental site are presented in Figure 1. Previous crop was cotton.

The field experiment was set up in Randomized Complete Block Design (RCBD) where blocks were fertilization. The treatments were control, NPK, (1250 kg ha $\left.{ }^{-1}\right)$, compost ( $526 \mathrm{~kg} \mathrm{ha}^{-1}$ ) and ruminant manure (250 kg ha-1). The NPK was ammonium sulfate (40-0-0). Chemical composition of manure is $\mathrm{pH}=8.1, \mathrm{EC}\left(\mathrm{dS} \mathrm{m} \mathrm{m}^{-1}\right)=4.2$, organic matter $(\%)$ $=31.3$ and total nitrogen $(\%)=0.93$. Respectively, for compost was $\mathrm{pH}=4.3, \mathrm{EC}\left(\mathrm{dS} \mathrm{m}{ }^{-1}\right)=1.3$, organic matter $(\%)=43.1$ and total nitrogen $(\%)=1.35$.

Supplementary fertilization was not applied. The surface of experimental area was $165 \mathrm{~m}^{2}$, 4 blocks and 16 plots $\left(6 \mathrm{~m}^{2}\right)$. Sowing date was $10 / 01 / 2020$. Seed rate was 410 seeds $\mathrm{m}^{-2}$, with row spacing $15 \mathrm{~cm}$ soil. Implements for tillage were included primary chisel plow (depth of 40 $\mathrm{cm}$ ), secondary disc harrow. Weed control was achieved handily. Harvest was done 161 DAS.

\section{Plant material}

'Bulel' is the second commercial cultivar of tritordeum (xTritordeum martinii A. Pujadas, nothosp. nov.) which was registered in 2013 in the CPVO (Community Plant Variety Office). It

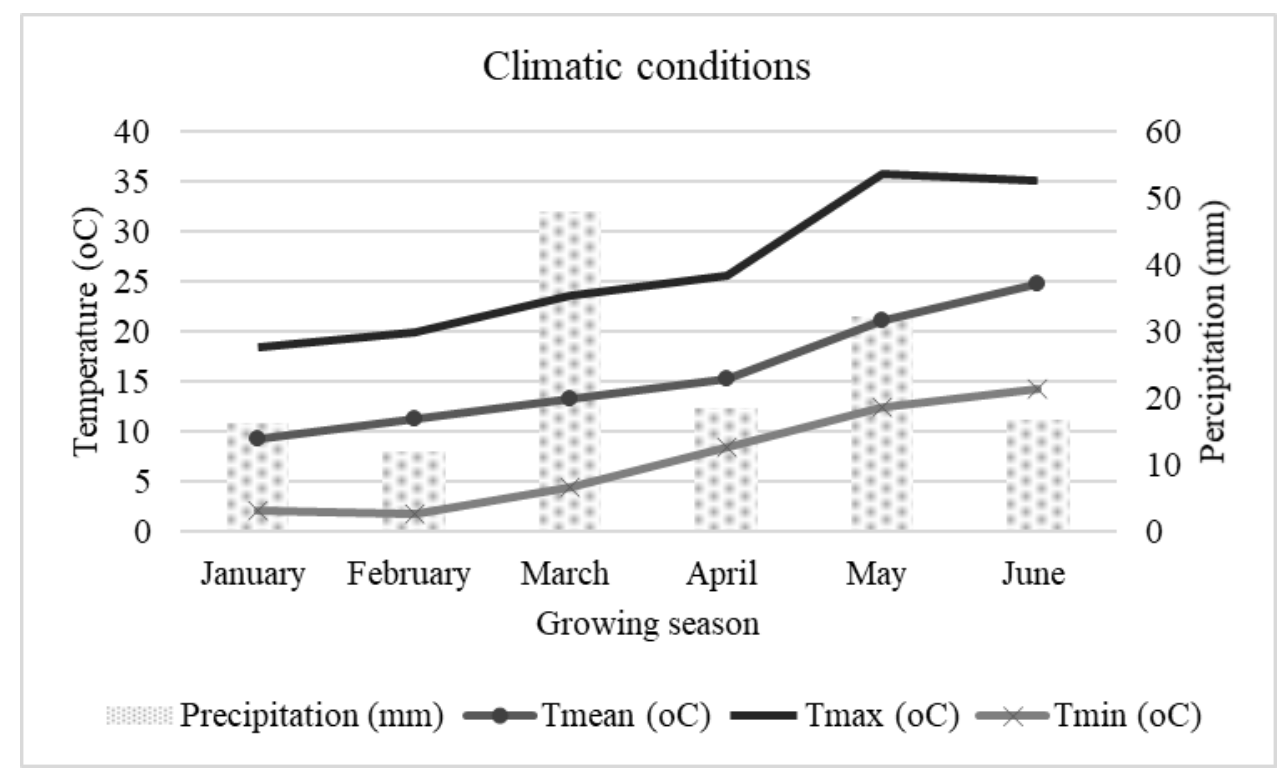

Figure 1: Meteorological data at experimental area for growing season 2020 The total precipitation was $144.2 \mathrm{~mm}$ for the growing season 
is characterized by the improved bread-making quality and high protein content.

\section{Sampling and analytical methods}

Plant height was noticed 140 DAS, average three plants per plot. Total protein (\%), seed moisture capacity (\%), grain specific weight and gluten content (\%) were determined using the Infratec ${ }^{\mathrm{TM}} 1241$ Grain Analyzer (FOSS, Eden Prairie, MN, USA, Serial no. 12417239) after harvest. The scanning temperature was controlled from $21^{\circ}-25^{\circ} \mathrm{C}$. The absorption wavelength range of the samples was 850-1050 nm. The 1000-grain weight was determined from a subsample of the grain harvested from each plot. Crude fiber (\%) was determined (AOAC, 1984).

\section{Calculations and statistics}

Analysis of variance was carried out on data using the Stat Soft (2011) logistic package as a Completely Randomized Block Design. The significance of differences between treatments was estimated by using Duncan test and probabilities equal to or less than 0.05 were considered significant.

\section{Results and discussion}

Plant height ranged from $65 \mathrm{~cm}$ (control) to $71.75 \mathrm{~cm}$ (NPK). Between organic fertilizations there was not observed significant difference. Similar results are noticed for the average internode length $(\mathrm{cm})$. Plant height is lower than the wheat parent (Baro et al., 1991). Karagoz et al. (2004) mentioned wheat plant height around $100 \mathrm{~cm}$. Martin et al. (1999) mentioned that traits such as plant height and biomass yield have range variation. In addition, 1000 seed weight ( $\mathrm{g}$ ) varied between $27.5 \mathrm{~g}$ (control) and $31.96 \mathrm{~g}$ (NPK).
These values are close to Erlandsson (2010) who observed a range of $38 \mathrm{~g}$ to $44 \mathrm{~g}$. This difference may be due to the seed moisture capacity, as Erlandsson (2010) reports seed moisture capacity at $14 \%$.

Also, yield was significantly affected by fertilization. Yield was significant higher with inorganic fertilization. Maximum value was 4753.5 $\mathrm{kg} \mathrm{ha}^{-1}$ (NPK) whereas minimum was 3210.75 $\mathrm{kg} \mathrm{ha}^{-1}$ (control). Inorganic fertilization resulted in $30 \%$ more yield than organic fertilization. Yield was only between $20-40 \%$ of that of wheat partially possibly due to the late heading date of tritordeum (Millán, 1988). Late anthesis date may cause lower yield under Mediterranean drought conditions (Millán et al., 1988; Villegas et al., 2010). In spite of sowing late, in our experiment yield was high. This can be explained by the combination of stable genotype and fertilization.

Inflorescence length did not statistically differ for three fertilizers, whereas yield differed for inorganic and organic fertilizers. Therefore, tritordeum inflorescence length does not mean higher yield. Villegas et al. (2010) use for yield components grain weight, spikes $\mathrm{m}^{-2}$; grains per spike.

Seed moisture capacity was not varied among fertilizations. The seed moisture capacity, for tritordeum seeds, 'Bulel' variety, was around $11 \%$. Seed moisture capacity varies from harvest date depending the sowing date. Seed moisture capacity were $9.1 \%$ and $7.9 \%$ for experimental lines T-3 and T-9 (Alvarez et al., 1992). Concerning gluten content, it was significant difference among fertilizations. Highest value was 33.45\% (NPK) and lowest 27.62\% (control). Gluten content in

Table 1. Mean values of height, 1000 seed weight, inflorescence length, average internode length, yield by fertilizers of variables measured in field experiments carried out during the 2020 season

\begin{tabular}{cccccc}
\hline Fertilization & Height (cm) & $\begin{array}{c}\mathbf{1 0 0 0} \text { seed } \\
\text { weight (g) }\end{array}$ & $\begin{array}{c}\text { Inflorescence } \\
\text { length (cm) 115 } \\
\text { DAS }\end{array}$ & $\begin{array}{c}\text { Average } \\
\text { internode } \\
\text { length (cm) }\end{array}$ & Yield (kg ha' $\mathbf{~}^{-1}$ ) \\
\hline Control & $65 \mathrm{a}$ & $27.52 \mathrm{a}$ & $13.1 \mathrm{a}$ & $14 \mathrm{a}$ & $3210.75 \mathrm{a}$ \\
\hline $\mathrm{NPK}$ & $71.75 \mathrm{~b}$ & $31.9 \mathrm{~b}$ & $14.5 \mathrm{~b}$ & $15.3 \mathrm{~b}$ & $4753.5 \mathrm{~b}$ \\
\hline Compost & $68 \mathrm{c}$ & $29 \mathrm{c}$ & $14.2 \mathrm{~b}$ & $14.6 \mathrm{a}$ & $3665.5 \mathrm{c}$ \\
\hline Manure & $68.9 \mathrm{c}$ & $29.8 \mathrm{c}$ & $14.3 \mathrm{~b}$ & $14.6 \mathrm{a}$ & $3806 \mathrm{c}$ \\
\hline
\end{tabular}

Note: Different letters within a column indicate significant differences at $\mathrm{P}<0.05$ according to the Duncan test 
Table 2. Mean values of protein, seed moisture capacity, Kernel weight, gluten, seed fiber concentrate, stem fiber concentrate by fertilizers of variables measured in field experiments carried out during the 2020 season

\begin{tabular}{lcccccc}
\hline Fertilization & Protein (\%) & $\begin{array}{c}\text { Seed } \\
\text { moisture } \\
\text { capacity (\%) }\end{array}$ & $\begin{array}{c}\text { Kernel } \\
\text { weight (kg } \\
\mathbf{h l}^{-1} \text { ) }\end{array}$ & Gluten (\%) & $\begin{array}{c}\text { Seed fiber } \\
\text { concentrate } \\
\text { (\%) }\end{array}$ & $\begin{array}{c}\text { Stem fiber } \\
\text { concentrate } \\
\text { (\%) }\end{array}$ \\
\hline Control & $11 \mathrm{a}$ & $10.7 \mathrm{a}$ & $66.82 \mathrm{a}$ & $27.62 \mathrm{a}$ & $4.06 \mathrm{a}$ & $35.37 \mathrm{a}$ \\
\hline NPK & $16.27 \mathrm{~b}$ & $11.025 \mathrm{a}$ & $71.4 \mathrm{~b}$ & $33.45 \mathrm{~b}$ & $3.92 \mathrm{~b}$ & $36.25 \mathrm{~b}$ \\
\hline Compost & $14.2 \mathrm{c}$ & $11.025 \mathrm{a}$ & $67.62 \mathrm{a}$ & $31.2 \mathrm{c}$ & $3.89 \mathrm{~b}$ & $36.46 \mathrm{~b}$ \\
\hline Manure & $14.12 \mathrm{c}$ & $11.025 \mathrm{a}$ & $67.92 \mathrm{a}$ & $31.7 \mathrm{c}$ & $3.94 \mathrm{~b}$ & $34.63 \mathrm{~b}$ \\
\hline
\end{tabular}

Note: Different letters within a column indicate significant differences at $\mathrm{P}<0.05$ according to the Duncan test

compost and manure did not differ, values were 31.2 and 31.7 respectively. Inorganic fertilization has a negative effect on gluten content as it increased the percentage as far as tritordeum is grown for less gluten than bread wheat.

Furthermore, there was no significant statistical difference between the two-organic fertilizations for protein content. Protein content was $14.6 \%$ higher in NPK fertilization compared to compost. Even in control, protein content was observed raised compared to bread wheat (Erlandsson, 2010). The high protein content, characteristic of primary tritordeum, is kept in improved lines (Millán, 1988). Tritordeum protein content can reach 25\% (Gallardo and Fereres, 1993).

Kernel weight ranged from 66.8 (control) to $71.4 \mathrm{~kg} / \mathrm{hl}$ (NPK). By Villegas et al. (2010) the highest value observed was $43.77 \mathrm{~kg} / \mathrm{hl}$. Alvarez et al. (1992) mention grain specific weight 44.9 $\mathrm{kg} / \mathrm{hl}$. This high difference may be explained by the genotype (Villegas et al., 2010). Indeed, 'Bulel' variety which was used in this experiment has become commercial later compared to literature. Therefore, large differences in values can be explained by the improvement of genotype.

Besides fiber, seed concentration was higher in control. The highest value of control was explained due to the lowest seed moisture capacity (Tab. 2). Erlandsson (2010) was mentioned for dietary fiber $14.3 \%$. Seed fiber and stem fiber concentration did not statistically differ with inorganic and organic fertilization. Stem fiber concentration was a characteristic for fodder quality of tritordeum before it being used in human diet. Daniels et al. (2000) mentioned that nitrogen fertilization had no effect on digestibility of forage and Collins et al. (1990) observed the same on neutral detergent fiber (NDF) or acid detergent fiber (ADF). On the contrary, in our experiment, fertilization was significantly affected by fertilization.

\section{Conclusion}

As first results, in Greece, tritordeum crop had a positive response to fertilization, especially in inorganic. Higher yield and protein content were observed under inorganic fertilization compared to organic. But gluten content increased with inorganic fertilization and this is a negative character as far as tritordeum is cultivated for lower levels of gluten. Gluten content was 5.5\% higher under inorganic fertilization in comparison with compost. This study indicated that inflorescence length is not the factor affecting the yield of tritordeum. Additionally, seed moisture capacity, 161 DAS, 'Bulel' variety was around 11\%. While it was noted that fertilization positively affected growth and quality characteristics of tritordeum, further study is needed because many characteristics are due to the genotype. In this study, although the sowing date was late comparatively to literature, the yield was observed raised up. Protein content was around 14\% higher in inorganic fertilization compared to organic. 


\section{References}

1. Alvarez JB, Ballesteros J, Sillero JA, Martin LM (1992). Tritordeum: a new crop of potential importance in the food industry. Hereditas, 116(1-2): 193-197.

2. Association of Official Analytical Chemists International (1984). Official Methods of Analysis, 14th edn. AOAC, Arlington, VA.

3. Blandino M, Visioli G, Marando S, Marti A, Reyneri A (2020). Impact of late-season $\mathrm{N}$ fertilisation strategies on the gluten content and composition of high protein wheat grown under humid Mediterranean conditions. Journal of Cereal Science, 102995.

4. Collins M, Brinkman MA, Salman AA (1990). Forage yield and quality of oat cultivars with increasing rates of nitrogen fertilization. Agronomy Journal, 82(4): 724-728.

5. Daniels LB, Harrison KF, Hubbell IIIDS, Johnson ZB (2001). Evaluation of Cultivars of Soft Red Winter Wheat for Forage for Stocker Cattle Production. Arkansas, 91.

6. De la Hera E, Martinez M, Oliete B, Gómez M (2013). Influence of flour particle size on quality of gluten-free rice cakes. Food and Bioprocess Technology, 6(9): 22802288.

7. De Santis MA, Giuliani MM, Flagella Z, Reyneri A, Blandino M (2020). Impact of nitrogen fertilisation strategies on the protein content, gluten composition and rheological properties of wheat for biscuit production. Field Crops Research, 107829.

8. Erlandsson A (2010). Tritordeum Evaluation of a new food cereal. Master thesis, Agricultural programme. Food Science, Swedish University of Agricultural Sciences, Uppsala.

9. Feuillet C, Langridge P, Waugh R (2008). Cereal breeding takes a walk on the wild side. Trends in genetics, 24(1): 24-32.

10. Gallardo M, Fereres E (1993). Grain protein and grain yield of tritordeum in comparison to wheat and triticale. Plant and soil, 153(2): 287-293.

11. Giordano D, Reyneri A, Locatelli M, Coïsson JD, Blandino M (2019). Distribution of bioactive compounds in pearled fractions of tritordeum. Food chemistry, 301, 125228.
12. Hernändez P, Barcelo P, Lazzeri PA, Flores F, Lörz H, Martin A (2000). Morphological and agronomic variation in transgenic Tritordeum lines grown in the field. Journal of plant physiology, 156(2): 223-229.

13. Martın A, Alvarez JB, Martın LM, Barro F, Ballesteros J (1999). The development of tritordeum: a novel cereal for food processing. Journal of Cereal Science, 30(2): 85-95.

14. Millán T, Martin A, De Haro A (1988). Field trial of tritordeum. Cereal research communication, 31-38.

15. Pinto RJB, Alvarez JB, Martín LM (2002). Preliminary evaluation of grain yield components in hexaploid tritordeum. Crop Breeding and Applied Biotechnology, $2(2)$.

16. Vaquero L, Comino I, Vivas S, Rodríguez-Martín L, Giménez, MJ, Pastor J, Barro F (2018). Tritordeum: A novel cereal for food processing with good acceptability and significant reduction in gluten immunogenic peptides in comparison with wheat. Journal of the Science of Food and Agriculture, 98(6): 2201-2209.

17. Vaquero L, Comino I, Vivas S, Rodríguez-Martín L, Giménez MJ, Pastor J, Sousa C, Barro F (2017). Tritordeum: a novel cereal for food processing with good acceptability and significant reduction in gluten immunogenic peptides in comparison with wheat. J. of the Sci. of Food and Agri., 98(6): 2201-2209.

18. Villegas D, Casadesús J, Atienza SG, Martos V, Maalouf F, Karam F, Nogués S (2010). Tritordeum, wheat and triticale yield components under multi-local mediterranean drought conditions. Field Crops Research, 116(1-2): 6874.

19. Wakley A, Black IA (1934). An examination of the Degtiareff methods for determining soil organic matter and a proposed modification of chromic acid titration method. Soil Science 37: 29-38.

20. Zdaniewicz M, Pater A, Szczepanik O, Duliński R, CiochSkoneczny M (2020). Tritordeum malt: An innovative raw material for beer production. Journal of Cereal; Science, 103095. 